\title{
Effects of dry period length on milk production, body condition, metabolites, and hepatic glucose metabolism in dairy cows
}

\author{
C. Weber, ${ }^{\star}$ B. Losand,† A. Tuchscherer,‡ F. Rehbock,† E. Blum,† W. Yang,§ R. M. Bruckmaier,\# \\ P. Sanftleben,† and H. M. Hammon*1 \\ *Institute of Nutritional Physiology "Oskar Kellner," Leibniz Institute for Farm Animal Biology (FBN), 18196 Dummerstorf, Germany \\ †State Institute of Animal Production, 18196 Dummerstorf, Germany \\ łInstitute of Genetics and Biometry, Leibniz Institute for Farm Animal Biology (FBN), 18196 Dummerstorf, Germany \\ §Nanjing Agricultural University, 210095 Nanjing, China \\ \#Veterinary Physiology, Vetsuisse Faculty, University of Bern, 3001 Bern, Switzerland
}

\begin{abstract}
Dry period (DP) length affects energy metabolism around calving in dairy cows as well as milk production in the subsequent lactation. The aim of the study was to investigate milk production, body condition, metabolic adaptation, and hepatic gene expression of gluconeogenic enzymes in Holstein cows $(>10,000 \mathrm{~kg}$ milk/305 d) with 28- $(\mathrm{n}=18), 56-(\mathrm{n}=18)$, and 90-d $\mathrm{DP}(\mathrm{n}=22)$ length (treatment groups) in a commercial farm. Cows were fed total mixed rations ad libitum adjusted for far-off (not for 28-d DP) and close-up DP and lactation. Milk yield was recorded daily and body condition score (BCS), back fat thickness (BFT), and body weight (BW) were determined at dry off, 1 wk before expected and after calving, and on wk 2, 4, and 8 postpartum (pp). Blood samples were taken on d $-56,-28,-7,1,7,14,28$, and 56 relative to calving to measure plasma concentrations of metabolites and hormones. Liver biopsies ( $\mathrm{n}=11$ per treatment) were taken on $\mathrm{d}-10$ and 10 relative to calving to determine glycogen and total liver fat concentration (LFC) and to quantify mRNA levels of pyruvate carboxylase $(P C)$, cytosolic phosphoenolpyruvate carboxykinase, and glucose-6-phosphatase. Time course of milk yield during first 8 wk in lactation differed among treatment. Milk protein content was higher in 28-d than in 90-d DP cows. Milk fat to protein ratio was highest and milk urea was lowest in 90-d DP cows. Differences in $\mathrm{BW}, \mathrm{BFT}$, and BCS were predominantly seen before calving with greatest BW, BFT, and BCS in 90-d DP cows. Plasma concentrations of NEFA and BHBA were elevated during the transition period in all cows, and the greatest increase pp was seen in 90-d DP cows. Plasma glucose concentration decreased around calving and was greater in 28-d than in $90-\mathrm{d}$ DP cows. Dry pe-
\end{abstract}

Received July 10, 2014.

Accepted November 12, 2014.

${ }^{1}$ Corresponding author: hammon@fbn-dummerstorf.de riod length also affected plasma concentrations of urea, cholesterol, aspartate transaminase, and glutamate dehydrogenase. Plasma insulin concentration decreased around calving in all cows, but insulin concentration pp was greater in 28-d than in 56-d DP cows. Hepatic glycogen concentration decreased and LFC increased after calving in all cows, and LFC was greater pp in 90-d DP than in 28-d DP cows. Hepatic PC mRNA abundance pp tended to increase most in 90-d DP cows. Changes on glucose metabolism were more balanced in cows with a reduced DP, whereas cows with extended DP and elevated body condition indicated greatest metabolic changes according to lipid and glucose metabolism during the transition period.

Key words: dairy cow, dry period length, glucose metabolism

\section{INTRODUCTION}

Dry period (DP) management by farmers is generally arranged by a 6 - to 8 -wk period to give the cow a resting time after lactation and in preparation for the next calving and lactation. It is well known that DP length influences milk production and composition, energy balance, and health in the consecutive lactation (Grummer and Rastani, 2004; Watters et al., 2008; van Knegsel et al., 2013). The dramatic increase of energy required after calving for milk production in high-yielding dairy cows and insufficient DMI at the same time lead to the well-described negative energy balance in early lactation (Ingvartsen and Andersen, 2000; Drackley et al., 2001). Shortening the DP length in dairy cows often results in decreased milk production, which is partly compensated by a greater milk yield during prolonged previous lactation, but reduces metabolic load at beginning of the subsequent lactation, as reviewed by Bachman and Schairer (2003) and van Knegsel et al. (2013). Besides milk production, effects of shortening DP length on glucose metabolism during the transition period are of interest. Providing sufficient glucose for milk production is a prerequisite 
for maximal milk performance (Linzell, 1972; Rigout et al., 2002). Recent studies in dairy cows revealed marked changes in adaptation of hepatic glucose production during the transition period to comply with the huge glucose demand after onset of lactation (Greenfield et al., 2000; Hammon et al., 2009; Weber et al., 2013a). Whether a shortened DP length affects hepatic glucose metabolism during the transition period in dairy cows is not yet known.

In addition, an extended DP length often occurs on farms due to a prolonged calving interval or other reasons. Insufficient milk production at the end of lactation prevents achievement of intended lactation cut off and foreseen DP length. Due to inadequate management, these cows often gain weight, fill up their fat depots, and their body condition increases. However, metabolic adaptation to consecutive lactation largely depends on body condition during previous lactation (Grummer, 1993; Drackley et al., 2001; Weber et al., 2013b). Elevated body condition before calving often leads to enhanced lipolysis around calving that results in moderate to severe metabolic load in dairy cows with increased plasma concentrations of NEFA and BHBA as well as enhanced fat storage in the liver (Grummer, 1993; Hammon et al., 2009; Weber et al., 2013b). Therefore, an extended DP might result in imbalances with respect to glucose and lipid metabolism during the transition period that impair consecutive lactation by developing disorders such as ketosis and fatty liver, but studies investigating this topic are rare.

The aim of the present study was to investigate the metabolic consequences of either an extended or a shortened DP length on metabolic changes during the transition and early lactation period with emphasis on glucose metabolism. The hypothesis was tested that an extended as well as a shortened DP length affects systemic and hepatic glucose metabolism in dairy cows when preparing for consecutive lactation. Besides measurements on milk performance, body condition, and metabolic changes in blood plasma, gene expression of key enzymes on hepatic gluconeogenesis that contribute to the metabolic adaptation around calving in dairy cows were investigated (Hammon et al., 2009; Weber et al., 2013a) and tested for their responses to different DP length.

\section{MATERIALS AND METHODS}

\section{Animals, Housing, Feeding, and Classification of Cows}

The experimental procedures were carried out according to the animal care guidelines and were approved by the relevant authorities of the State Mecklenburg-Vorpommern, Germany (LALLF M-V/
TSD/7221.3-2.1-021/06). Multiparous (lactation number 2 to 8$)$ German Holstein cows $(\mathrm{n}=58)$ with comparable milk production $(>10,000 \mathrm{~kg} / 305 \mathrm{~d}$ during preceding lactation) on a conventional farm (Gut Dummerstorf GmbH, Dummerstorf, Germany) were selected for this experiment. Cows were kept in a free-stall barn with deep lying boxes filled with chaffed straw. One week before expected calving cows were moved in calving boxes with straw, immediately after calving cows were moved into the fresh cow group for 6 consecutive days, and after this period relocated to the lactational transition group. Cows were studied from dry off to 56 DIM in the consecutive lactation. Cows were grouped into shortened (28-d DP; $\mathrm{n}=18$ ) and conventional (56d DP; $\mathrm{n}=18$ ) DP before expected calving. A third treatment group was created by cows with an extended (90-d; $\mathrm{n}=22)$ DP before expected calving. Actual DP lengths were (mean $\pm \mathrm{SE}) 26 \pm 3.3,56 \pm 4.5$, and $98 \pm$ $22.7 \mathrm{~d}$ for $28-, 56-$, and $90-\mathrm{d}$ DP treatment, respectively. Cows with 28- and 56-d DP were selected randomly and were blocked on milk yield and DIM of previous lactation and on lactation number. Cows with 90-d DP were selected due to the decline in milk yield $(<15 \mathrm{~kg}$ /d) during late lactation. The dry-off protocol included treatment of all cows with intramammary applied antibiotics (Cloxacillin, Pfizer Corporation, Wien, Austria) after last milking.

The experimental groups were fed with TMR ad libitum during the DP (far-off and close-up ration), and lactation. Cows with 56- and 90-d DP were first fed with the far-off diet from dry off until wk 4 before the expected calving date, and afterward were fed the close-up diet from wk 3 before expected calving to parturition. Cows with the 28-d DP were moved after dry off to the close-up pen and fed only the close-up ration during DP. After calving all groups received the same lactation diet until 56 DIM. Diets were fed 2 times a day at 0700 and $1300 \mathrm{~h}$, and TMR was shoveled closer to the feedlot in a time interval of $4 \mathrm{~h}$. Ingredients and chemical composition of the different diets are shown in Table 1. Dry matter, utilizable protein, crude fat, $\mathrm{NE}_{\mathrm{L}}, \mathrm{ADF}$, and NDF were determined according to Naumann and Bassler (2004). Cows always had free access to water troughs.

\section{Measurement of Milk Yield, Milk Composition, and Body Condition}

Cows were milked thrice per day at 0600, 1400, and $2200 \mathrm{~h}$. Milk yield was electronically recorded at each milking. Milk samples were taken monthly from 3 milkings during the day and were pooled for the determination of protein, fat, lactose, and urea concentrations in milk. Analyses of milk components were conducted 
Table 1. Ingredients and chemical composition of diets for the far-off dry period, close-up dry period, and lactation period fed during the study to dairy cows with 28-, 56-, and 90-d dry period length

\begin{tabular}{|c|c|c|c|}
\hline \multirow[b]{2}{*}{ Item } & \multicolumn{3}{|c|}{ Diet } \\
\hline & Far-off ${ }^{1}$ & Close-up ${ }^{1}$ & Lactation $^{1}$ \\
\hline \multicolumn{4}{|l|}{ Ingredient } \\
\hline Corn silage, $\mathrm{g} / \mathrm{kg}$ of $\mathrm{DM}$ & 276 & 500 & 401 \\
\hline Grass silage, $\mathrm{g} / \mathrm{kg}$ of $\mathrm{DM}$ & 630 & 252 & 144 \\
\hline Barley straw, $\mathrm{g} / \mathrm{kg}$ of DM & 63 & 28 & 10 \\
\hline Extracted rapeseed meal, $\mathrm{g} / \mathrm{kg}$ of DM & & 30 & 64 \\
\hline Beet pulp, $\mathrm{g} / \mathrm{kg}$ of DM & & & 13 \\
\hline Grain meal, $\mathrm{g} / \mathrm{kg}$ of DM & 22 & 42 & 68 \\
\hline Corn meal, $\mathrm{g} / \mathrm{kg}$ of DM & & 33 & 83 \\
\hline Soybean meal, $\mathrm{g} / \mathrm{kg}$ of DM & & 37 & 40 \\
\hline Molasses, sugarbeet, $\mathrm{g} / \mathrm{kg}$ of $\mathrm{DM}$ & & 4 & 27 \\
\hline Panto TMR ${ }^{2} \mathrm{~g} / \mathrm{kg}$ of DM & & 45 & 39 \\
\hline Panto Power Mix, ${ }^{3} \mathrm{~g} / \mathrm{kg}$ of DM & & 10 & 32 \\
\hline Propylene glycol, $\mathrm{g} / \mathrm{kg}$ of DM & & 11 & 9 \\
\hline Minerals, $\mathrm{g} / \mathrm{kg}$ of DM & $9^{4}$ & $8^{4}$ & $13^{5}$ \\
\hline \multicolumn{4}{|l|}{ Chemical analysis $^{6}$} \\
\hline Utilizable protein, $\mathrm{g} / \mathrm{kg}$ of $\mathrm{DM}$ & 129 & 132 & 145 \\
\hline Crude fat, $\mathrm{g} / \mathrm{kg}$ of DM & 28 & 50 & 55 \\
\hline $\mathrm{NE}_{\mathrm{L}}, \mathrm{MJ} / \mathrm{kg}$ of $\mathrm{DM}$ & 5.9 & 6.7 & 7.3 \\
\hline $\mathrm{ADF}, \mathrm{g} / \mathrm{kg}$ of $\mathrm{DM}$ & 281 & 197 & 165 \\
\hline $\mathrm{NDF}, \mathrm{g} / \mathrm{kg}$ of $\mathrm{DM}$ & 487 & 351 & 300 \\
\hline
\end{tabular}

${ }^{1}$ Far-off period was from dry off to wk 4 before calving and close-up period was from wk 1 to wk 1 before calving.

${ }^{2}$ Protein concentrate: Panto-Potent TMR (HL Hamburger Leistungsfutter GmbH, Hamburg, Germany): $40.00 \%$ CP, $5.00 \%$ crude fat, $6.50 \%$ crude fiber, $7.00 \%$ crude ash, $0.50 \%$ calcium, $0.70 \%$ phosphorus, $0.10 \%$ sodium, $0.30 \%$ magnesium.

${ }^{3}$ Energy concentrate: Panto Power Mix (HL Hamburger Leistungsfutter GmbH): $46.00 \%$ crude fat, $20.00 \%$ sugar, $12.00 \%$ starch, $9.00 \%$ crude protein.

${ }^{4}$ Nonlactating minerals: Panto/ATR R 7880 (ATR Landhandel GmbH \& Co. KG, Ratzeburg, Germany): 0.00\% calcium, $8.00 \%$ phosphorus, $3.50 \%$ sodium, $10.00 \%$ magnesium, and vitamins (per kilogram of nonlactating minerals: 1,000,000 IU of vitamin A, 200,000 IU of vitamin $\mathrm{D}_{3}$, and 20,000 $\mathrm{mg}$ of vitamin $\mathrm{E}$ )..

${ }^{5}$ Lactating minerals: Panto/ATR R 7690 (ATR Landhandel GmbH \& Co. KG): $20.00 \%$ calcium, $8.00 \%$ phosphorus, $10.00 \%$ sodium, $5.00 \%$ magnesium, and vitamins (per kilogram of lactating minerals: 500,000 IU of vitamin $\mathrm{A}, 65,000 \mathrm{IU}$ of vitamin $\mathrm{D}_{3}$, and $3,500 \mathrm{mg}$ of vitamin $\mathrm{E}$ ).

${ }^{6}$ German Society of Nutrition Physiology (2008).

by the Landeskontrollverband für Leistungs- und Qualitätsprüfung Mecklenburg-Vorpommern e.V. (Güstrow, Germany), using an infrared spectrophotometric method (Milcosan, Foss Germany, Rellingen, Germany). Energycorrected milk was calculated as described by Reist et al. (2003): $\mathrm{ECM}(\mathrm{kg})=(0.038 \times \mathrm{g}$ crude fat $+0.024 \times \mathrm{g}$ of $\mathrm{CP}+0.017 \times \mathrm{g}$ of lactose $) \times \mathrm{kg}$ of milk $/ 3.14$.

Body weight, back fat thickness (BFT), and BCS were measured at dry off, wk 1 before expected calving, and on wk 1, 2, 4, and 8 after calving. Back fat thickness was recorded by ultrasonic measurement (ALOKA SSD 500, Aloka, Meerbusch, Germany) in the sacral region according to Schröder and Staufenbiel (2006) and BCS was determined on an 1- to 5-point scale according to Edmonson et al. (1989).

\section{Blood Sampling and Analyses of Metabolites and Hormones in Plasma}

Blood samples were taken from the coccygeal vein at dry off and on d 56, 28, and 7 before expected calv- ing, and on 1, 7, 14, 28, and 56 DIM using evacuated tubes (Vacuette, Greiner Bio-One International AG, Frickenhausen, Germany) containing potassium-EDTA $\left(\mathrm{K}_{3}\right.$ EDTA $1.8 \mathrm{~g} / \mathrm{L}$ of blood) as an anticoagulant. Individual blood sampling varied from $1 \mathrm{~d}$ before to $1 \mathrm{~d}$ after the exact date. Blood samples were immediately put on ice, and then centrifuged at $1,500 \times g$ at $4^{\circ} \mathrm{C}$ for $20 \mathrm{~min}$. The supernatant was harvested and stored at $-20^{\circ} \mathrm{C}$ until analyzed for NEFA, BHBA, glucose, cholesterol, urea, aspartate transaminase (AST), glutamate dehydrogenase (GLDH), insulin, and glucagon. Plasma metabolites (NEFA, BHBA, glucose, cholesterol, urea) and enzymes (AST, GLDH) were analyzed by the Klinik für Rinder (Stiftung Tierärztliche Hochschule Hannover, Germany) using respective kits: NEFA (\#434-91795) from WAKO Chemicals GmbH, Neuss, Germany; BHBA (\#RB 1008) from Randox Laboratories Ltd., Crumlin, UK; glucose (\#553-230), cholesterol (\#553-124), and AST (\#553-256 G) from MTI-Diagnostics, Idstein, Germany; urea (\#LT-UR 0050) from Labor + Technik, E. Lehmann, Salzburg, 
Austria; GLDH (\#11929992) from Roche Diagnostics, Mannheim, Germany. Analyses were performed automatically by spectophotometry (Pentra 400, Axon Lab, Reichenbach, Germany). Plasma insulin concentration was determined by radioimmunoassay as described (Vicari et al., 2008), and plasma glucagon concentration was detected by radioimmunoassay using a kit from Linco (GL-32K, Linco Research, St. Charles, MO; Vicari et al., 2008).

\section{Liver Tissue Sampling and Analyses}

Liver tissue samples were obtained by needle biopsy under local anesthesia on d 10 before expected calving and on d 10 after calving in each treatment group (first 11 cows per treatment group, respectively; Duske et al., 2009; Weber et al., 2013b). After cutting the skin, liver tissue was extracted using a tailor-made biopsy needle (outer diameter $6 \mathrm{~mm}$ ). Tissue samples were immediately frozen in liquid nitrogen and stored at $-80^{\circ} \mathrm{C}$ until analysis. Tissue was homogenized under liquid nitrogen. Carbon and nitrogen contents were analyzed by combustion and elemental analysis using mass spectrometry (EA 1108, Carlo Erba Instruments, Rodano, Italy; Delta S, Finnigan MAT, San Jose, CA). The concentration of total liver fat was calculated according to the following equation: liver fat $(\% \mathrm{DM})=$ $1.3038 \times \mathrm{C}(\% \mathrm{DM})-4.237 \times \mathrm{N}(\% \mathrm{DM})-0.58 \times$ glycogen $(\% \mathrm{DM})-0.5215 \times$ glucose $(\% \mathrm{DM})($ Duske et al., 2009). Liver glycogen concentration (LGC) was determined using a commercial photometric test kit based on amyloglucosidase-catalyzed release of glucose (no. 10207748035, Boehringer Mannheim, Mannheim, Germany; Duske et al., 2009).

Total RNA was isolated from liver samples, transcribed into cDNA and purified as described (Hammon et al., 2009). Genes involved in hepatic carbohydrate metabolism were cytosolic phosphoenolpyruvate carboxykinase $(\boldsymbol{P C K} \mathbf{1})$, pyruvate carboxylase $(\boldsymbol{P C})$, and glucose-6-phosphatase $(\boldsymbol{G} \boldsymbol{6} \boldsymbol{P C})$. Specific primer sequences were used as described by Hammon et al. (2009). Quantification of mRNA abundance relative to reference genes in liver tissue was done by real-time reverse-transcription PCR (LightCycler, Roche Applied Science, Mannheim, Germany) using SYBR Green I as fluorescent dye according to Pfaffl (2001). The reference gene used was $\beta$-actin $(\boldsymbol{A} \boldsymbol{C T \boldsymbol { B }})$ because it was not affected by DP length and time. This was not the case for glyceraldehyde-3-phosphate dehydrogenase, which was also tested as reference gene. After detection, melting temperatures were checked for specificity of each product. Additionally, gel electrophoresis of the PCR product demonstrated only one single band of the expected size. Products were verified by sequencing using an ABI Sequencing kit (ABI Big Dye Terminator, Applied Biosystems, Darmstadt, Germany) and an ABI 310 Genetic Analyzer (Applied Biosystems). Values of crossing point (quantification cycle; Cq) were corrected for different runs by an internal standard $(\Delta \mathrm{Cq})$. In addition, $\Delta \mathrm{Cq}_{A C T B}$ was used to normalize measurements of target genes as indicated by $\Delta \Delta \mathrm{CP}=$ $\Delta \mathrm{Cq}_{\mathrm{target}}-\Delta \mathrm{C}_{\mathrm{q} A C T B}$ (Hammon et al., 2009). Efficiency of PCR was close to 2 and inter- and intraassay coefficients of variation for reverse transcription-PCR of target and reference genes were $<1 \%$ (Hammon et al., 2009; Weber et al., 2013a).

\section{Statistical Analyses}

Statistical analyses were done with SAS for Windows, release 9.4 (SAS Institute Inc., Cary, NC). All data were analyzed by repeated measurements ANOVA using the MIXED procedure. The ANOVA models used contained the fixed effects DP length (levels: 28, 56 , and $90 \mathrm{~d}$ ); time (levels: day or week relative to calving as described above); the interaction between DP length and time, lactation number, the interaction between DP length and lactation number; and the interaction between DP length, time, and lactation number. Classes for lactation number were 2, 3, and $4+$ (4 and higher). Lactation number and respective interactions were excluded from the statistical model when not significant. Repeated measures on each cow were taken into account using the repeated statement of the MIXED procedure with autoregressive residual covariance structure for milk yield, milk ingredients, liver fat concentration (LFC), LGC, and hepatic gene expression data. Body condition data (BW, BCS, and $\mathrm{BFT}$ ) and plasma levels of metabolites, enzymes, and hormones were assessed by using an unstructured type of the block diagonal residual covariance matrix. The levels of the repeated variable time were d 56 before to 56 after calving for the entire observation period for metabolites, enzymes, and hormones and wk 1 before to wk 8 after calving for body condition data; $\mathrm{d}-56$ to -7 for the antepartum period (metabolites, enzymes, and hormones only); d 1 (wk 1) to d 56 (wk 8) after calving for the postpartum period. Days 90, 56, and 28 before expected calving were defined as day of dry off for individual treatment groups, respectively. Data were analyzed separately for each observation period for BW, BCS, BFT, and plasma concentrations of metabolites, enzymes, and hormones. Liver glycogen, LFC, and gene expression data were analyzed by the same model as described with $-10 \mathrm{~d}$ before expected calving and 10 DIM as time levels. The least squares means and their standard errors were computed for each fixed effect in the ANOVA model to display the results. Additionally, 
all pairwise differences of these least squares means were tested using the Tukey-Kramer procedure. Test results with $P<0.05$ were considered to be significant.

\section{RESULTS}

\section{Milk Yield, ECM, Milk Composition, $B W, B F T$, and $B C S$}

Calving interval was greater $(P<0.05)$ in $90-\mathrm{d}$ DP than in 28- and 56-d DP cows, but DIM and milk yield of previous lactation were not different among treatment groups (Table 2). Milk yield on day of dry off was higher $(P<0.05)$ in 56-d than in 90-d DP cows. Milk yield in subsequent lactation increased in all treatment cows $(P<0.001)$ from the onset of lactation to wk 6 , but milk yield proceeded differently among DP length (interaction DP length $\times$ time: $P<0.05$; Figure $1 \mathrm{~A}$; Table 3$)$. Dry period length differently affect milk yield with respect to lactation number. In 28-d DP cows, milk yield was greater in cows with 4 and higher lactation number than in cows with second lactation. Milk yield was recorded until 200 DIM and mean milk yield was $37.1,39.4$, and $41.8 \pm 1.7 \mathrm{~kg} / \mathrm{d}(\mathrm{LSM} \pm \mathrm{SE})$ for 28-, 56-, and 90-d DP cows, respectively. Milk yield decreased during that period in all cows and a trend $(P$ $=0.11$ ) was observed for greater milk yield in 90 -d than in 28-d DP cows.

Energy-corrected milk yield increased during lactation $(P<0.01)$, and the increase was greatest for $90-\mathrm{d}$ DP cows (interaction DP $\times$ time: $P<0.05$; Figure 1B, Table 3). Effects of DP length on ECM were influenced by lactation number. In 90-d DP cows, ECM was greater in cows of second lactation than in cows of third lactation. Milk fat content decreased $(P<0.001)$ in all cows during the experimental period. Milk protein content decreased $(P<0.01)$ from wk 2 to 5 after calving, but increased $(P<0.01)$ from wk 5 to 8 , and was greater $(P<0.01)$ in 28 -d DP than in $90-\mathrm{d}$ DP cows.
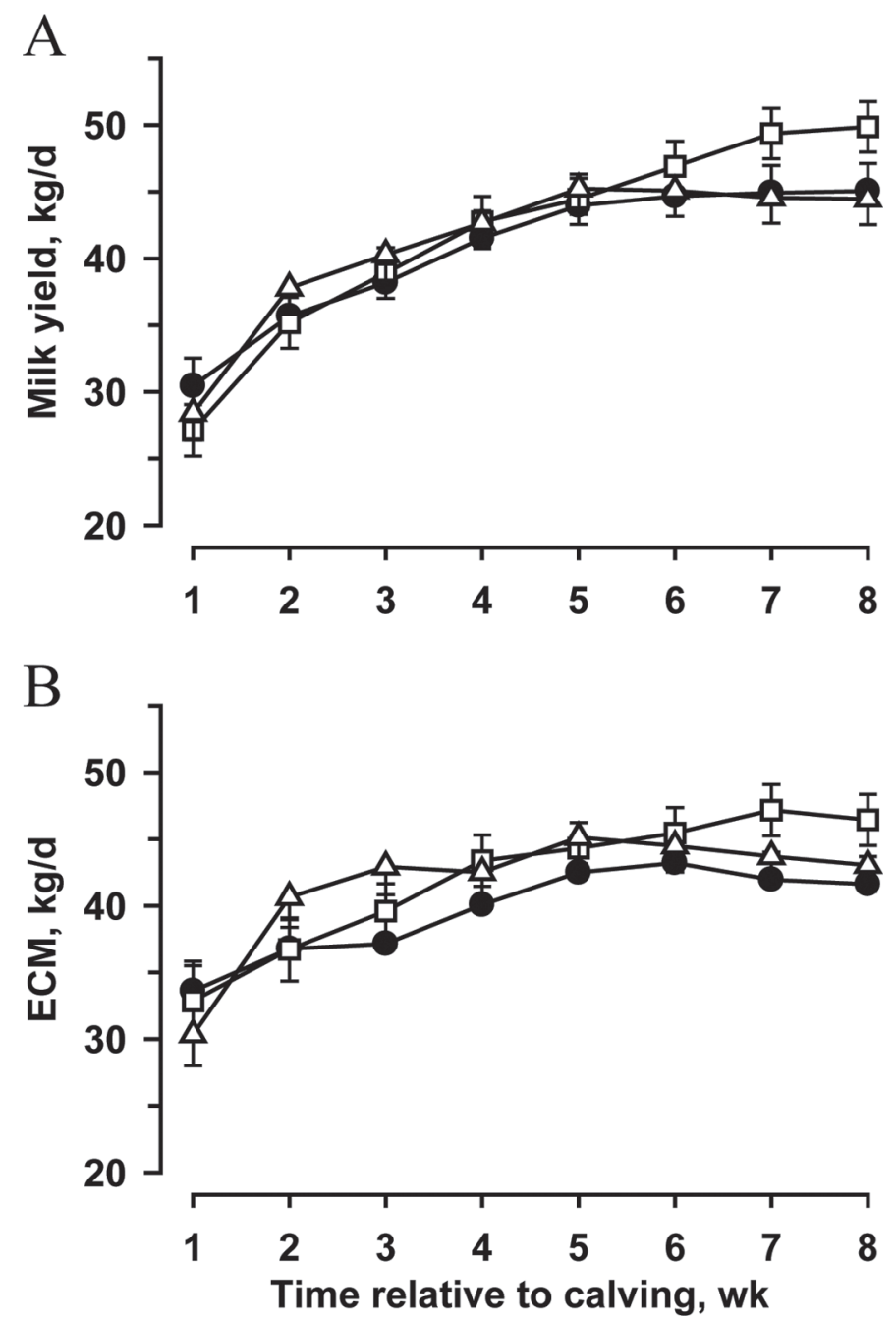

Figure 1. Milk yield (A) and ECM (B) from wk 1 to 8 after calving in cows with 28- $(\Delta), 56-(\bullet)$, and 90-d $(\square)$ dry period (DP) length. Data are presented as LSM \pm SE. Statistically significant $(P<0.05)$ effects for milk yield: time, DP length $\times$ time, DP length $\times$ lactation number. Statistically significant $(P<0.05)$ effects for ECM: time, DP length $\times$ time, DP length $\times$ lactation number.

Table 2. Number of lactations, milk yield, and DIM of previous lactation, and milk yield at dry off in cows with $28-(\mathrm{n}=18), 56-(\mathrm{n}=18)$ or $90-\mathrm{d}(\mathrm{n}=22)$ dry period (DP) length

\begin{tabular}{|c|c|c|c|c|c|}
\hline Variable $^{1}$ & \multicolumn{3}{|c|}{ DP } & $\mathrm{SE}$ & $\frac{(\text { ANOVA })}{P \text {-value }}$ \\
\hline No. of lactations ${ }^{2}$ & 3.1 & 3.3 & 4.1 & 0.4 & 0.1 \\
\hline DIM of previous lactation & 384 & 331 & 394 & 24 & 0.2 \\
\hline Milk yield of previous lactation, $\mathrm{kg} / 305$ DIM & 10,390 & 10,424 & 10,469 & 546 & 1.0 \\
\hline Milk yield at dry off, $\mathrm{kg} / \mathrm{d}$ & $17.4^{\mathrm{ab}}$ & $21.0^{\mathrm{a}}$ & $16.2^{\mathrm{b}}$ & 1.3 & 0.05 \\
\hline
\end{tabular}

\footnotetext{
$\overline{a, b}$ Least squares means with different letters within a row are significantly different from each other (Tukey-Kramer test, $P<0.05$ ).

${ }^{1}$ Values are LSM with SE.

${ }^{2}$ Lactation numbers of cows were $2(\mathrm{n}=7), 3(\mathrm{n}=6), 4+(\mathrm{n}=5)$ in cows with 28 -d DP length; $2(\mathrm{n}=10), 3(\mathrm{n}=3)$, and $4+(\mathrm{n}=5)$ in cows with 56-d DP length; and $2(\mathrm{n}=3), 3(\mathrm{n}=9)$, and $4+(\mathrm{n}=10)$ in cows with 90-d DP length.
} 
Table 3. Milk yield, ECM from wk 1 to 8 after calving, and milk fat, milk protein, and milk lactose, milk fat to protein ratio, and milk urea from wk 2 to 8 after calving in cows with $28-(\mathrm{n}=18), 56-(\mathrm{n}=18)$, or $90-\mathrm{d}(\mathrm{n}=22)$ dry period (DP) length

\begin{tabular}{|c|c|c|c|c|c|c|c|}
\hline \multirow[b]{2}{*}{ Variable $^{1}$} & \multicolumn{3}{|c|}{$\mathrm{DP}$} & \multirow[b]{2}{*}{$\mathrm{SE}$} & \multicolumn{3}{|c|}{$($ ANOVA) $P$-value } \\
\hline & $28-\mathrm{d}$ & $56-\mathrm{d}$ & $90-\mathrm{d}$ & & $\mathrm{DP}$ & Time & $\mathrm{DP} \times$ time \\
\hline $\mathrm{ECM}, \mathrm{kg} / \mathrm{d}$ & 41.6 & 39.6 & 42.0 & 1.6 & 0.6 & 0.001 & 0.02 \\
\hline Milk fat, $\mathrm{g} / \mathrm{kg}$ of milk & 43.0 & 40.9 & 42.3 & 1.5 & 0.6 & 0.001 & 0.5 \\
\hline Milk fat, $\mathrm{kg} / \mathrm{d}$ & 1.78 & 1.64 & 1.76 & 0.08 & 0.4 & 0.01 & 0.8 \\
\hline Milk protein, $\mathrm{g} / \mathrm{kg}$ of milk & $32.8^{\mathrm{a}}$ & $31.7^{\mathrm{ab}}$ & $29.8^{\mathrm{b}}$ & 0.65 & 0.01 & 0.01 & 0.1 \\
\hline Milk lactose, $\mathrm{g} / \mathrm{kg}$ of milk & 47.4 & 47.4 & 47.8 & 0.33 & 0.7 & 0.001 & 0.07 \\
\hline Milk lactose, $\mathrm{kg} / \mathrm{d}$ & 2.01 & 1.93 & 2.06 & 0.1 & 0.7 & 0.001 & 0.05 \\
\hline Milk urea, $\mathrm{mg} / \mathrm{kg}$ of milk & $258^{\mathrm{a}}$ & $268^{\mathrm{a}}$ & $210^{\mathrm{b}}$ & 7.9 & 0.01 & 0.2 & 0.07 \\
\hline
\end{tabular}

$\overline{{ }^{a}, \mathrm{~b}}$ Least squares means with different letters within a row are significantly different from each other (Tukey-Kramer test, $P<0.05$ ).

${ }^{1}$ Values are LSM with SE.

The fat to protein ratio decreased $(P<0.01)$ from wk 2 to 8 after calving. In $90-\mathrm{d}$ DP cows, the fat to protein ratio was greater $(P<0.01)$ than in $28-\mathrm{DP}$ cows and tended to be greater $(P<0.1)$ than in 56 -d DP cows (Table 3). Milk lactose content increased $(P<0.01)$ from wk 2 to 5 in all cows and was greater $(P<0.05)$ in $4+$ than in third lactation. Milk fat and lactose yield increased $(P<0.01)$ from wk 2 to 5 , but milk fat yield decreased $(P<0.05)$ from wk 5 to 8 . Milk lactose yield further increased $(P<0.05)$ from wk 5 to 8 only in $90-\mathrm{d}$ DP cows. Milk protein yield increased $(P<0.05)$ during the whole experimental period with the strongest increase $(P<0.01)$ in 90 -d DP cows. In $90-\mathrm{d}$ DP cows, milk fat yield was greater $(P<0.05)$ and milk protein yield tended to be greater $(P<0.1)$ in second than third lactation. Milk urea concentration was lowest $(P$ $<0.05$ ) in 90-d DP cows (Table 3).

Cows with 90-d DP tended to have higher BW ( $P=$ $0.08)$ at dry off than cows with $28-$ and 56 -d DP. Cows with different DP length gained BW $(P<0.01)$ during DP (Figure 2A). Before calving BW was higher $(P<$ $0.05)$ in 90 -d than in 28- and 56-d DP cows. After calving BW rapidly decreased $(P<0.05)$ in all cows up to wk 2 and remained relatively constant up to the end of the study. With respect to the whole experimental period, BW was lower $(P<0.05)$ in 56 -d DP than in 90 -d DP cows. At dry off and during the precalving period, BFT was highest $(P<0.01)$ in cows with $90-\mathrm{d}$ DP. After calving, all cows mobilized subcutaneous back fat from wk 1 to $4(P<0.01)$, whereby 90-d DP cows had always slightly higher BFT levels than 28- and 56-d DP cows at this time $(P=0.09$, Figure $2 \mathrm{~B})$. Body condition score was higher at dry off in cows with 90-d DP than in 28- and 56-d DP cows $(P<0.05$, Figure $2 \mathrm{C})$, but differences among cows disappeared before calving. After calving, BCS decreased $(P<0.01)$ in all cows to a similar extent to the end of the observation period.

\section{Metabolic and Endocrine Changes in Blood Plasma}

Plasma NEFA concentration was not different at dry off among cows, and increased $(P<0.001)$ around parturition in all cows (Figure 3A), showing greatest concentration on d 1, 7, and 14 after calving in 90-d DP cows $(P<0.001$; Figure 3A; Table 4$)$. Thereafter, plasma NEFA concentration decreased $(P<0.01)$ in all cows up to 56 DIM. Plasma BHBA concentration was lower $(P<0.05)$ at dry off in $90-\mathrm{d}$ DP than in 28 -d DP cows (Table 4). Plasma BHBA increased highest $(P$ $<0.01$ ) around calving in 90-d DP cows (Figure 3B; Table 4). Plasma glucose concentration was similar at dry off and during DP among cows, but decreased $(P$ $<0.01$ ) in 90-d DP cows on d 1 and in 28- and 56-d DP cows on d 7 after calving. During the entire study, plasma glucose concentration was higher $(P<0.05)$ in 28-d DP than in 90-d DP cows (Table 4; Figure 3C).

Plasma cholesterol concentration did not differ among cows at dry off (Table 4$)$, but decreased $(P<$ $0.01)$ during the DP and increased $(P<0.01)$ after calving in all cows (Figure 3D). With respect to the entire study, cholesterol concentration was higher $(P<$ $0.05)$ in 28-d DP than in 90-d DP cows and tended to be higher $(P<0.1)$ in 28 -d DP than in 56 -d DP cows. Cholesterol concentration on d 56 before expected calving was higher $(P<0.05)$ in 28 -d DP than in $90-\mathrm{d}$ DP cows and on d 28 before expected calving was highest $(P<0.05)$ in $28-\mathrm{d}$ DP cows. Plasma urea concentration was lowest on d 56 before expected calving and highest on 1 DIM in 90-d DP cows $(P<0.05)$ and increased $(P$ $<0.05)$ from 1 to 56 DIM in 56-d DP cows (Figure 3E; Table 4). Urea concentration was lowest $(P<0.05)$ on 28 DIM in $90-d$ DP cows and was lower $(P<0.05)$ on 56 DIM in 90-d DP than in 56-d DP cows.

Plasma AST concentration was similar at dry off in all cows, increased $(P<0.01)$ around calving in all 

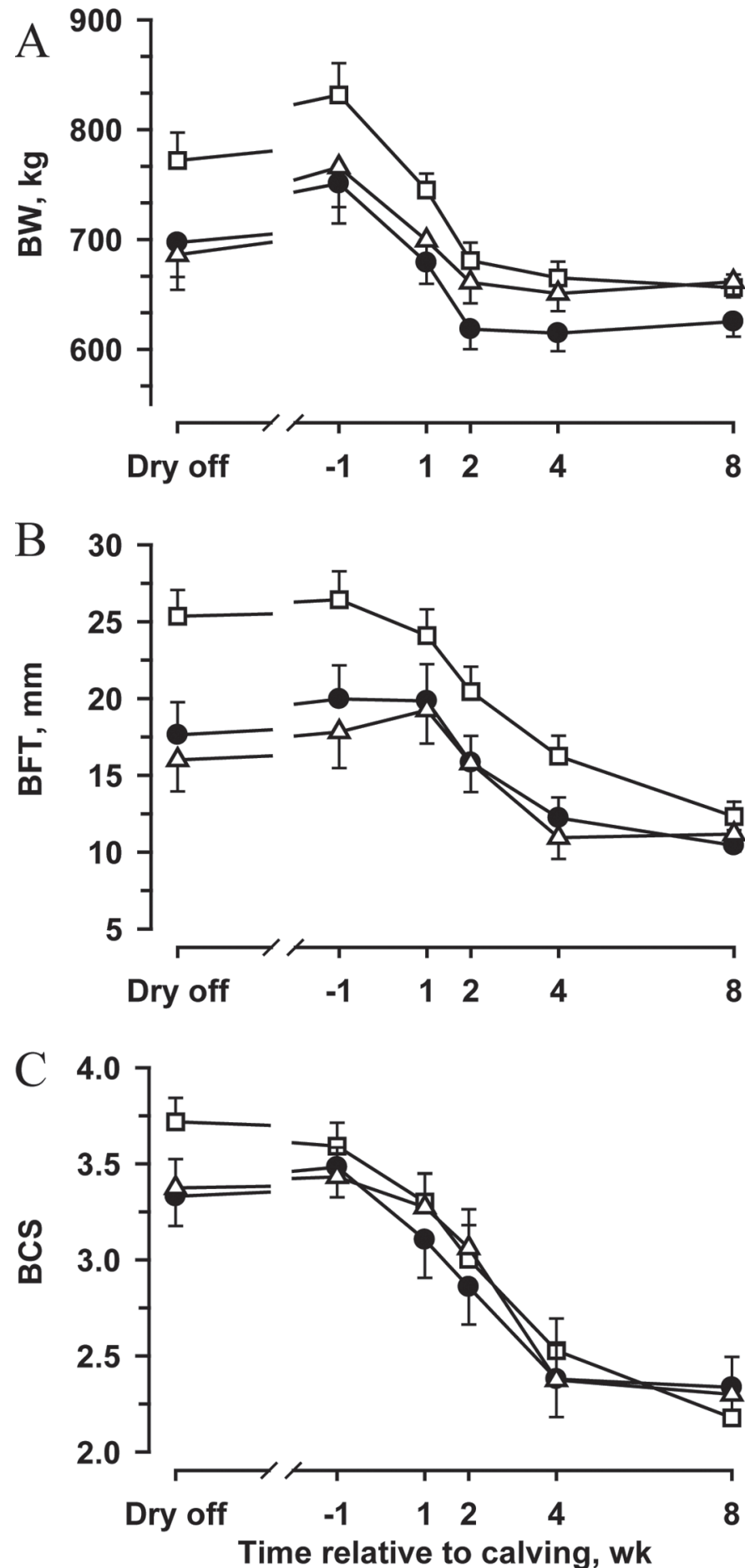

Figure 2. Body weight (A), backfat thickness (BFT; B), and BCS (C) on day of dry off and from wk 1 before expected calving to wk 8 after calving in cows with 28- $(\Delta), 56-(\bullet)$, and 90-d ( $\square$ ) dry period (DP) length. Data are presented as LSM \pm SE. Statistically significant $(P<0.05)$ effects for BW antepartum (ap): DP, time; postpartum (pp): time; entire study: DP, time. Statistically significant $(P<0.05)$ effects for BFT on d of dry off: DP; ap: DP; pp: time; entire study: DP, time. Statistically significant $(P<0.05)$ effects for BCS on d of dry off: DP; pp: time; entire study: time. cows, but greatest increase was observed at 7 DIM in 90-d DP cows $(P<0.05$, Table 4; Figure 3F). With respect to entire study AST concentration was higher $(P<0.05)$ in $90-\mathrm{d}$ DP than in 56-d DP cows. At dry off, plasma GLDH concentration of 56-d DP cows was higher $(P<0.05)$ than in 28-d DP cows and tended to be higher than in 90-d DP cows $(P<0.1$, Table 4$)$. After calving, GLDH concentration increased highest $(P<0.05)$ in $90-\mathrm{d}$ DP cows (interaction DP $\times$ time: $P$ $<0.05$ ), but concentration did not differ among cows at specific time points (Figure $3 \mathrm{G}$ ).

Plasma insulin and glucagon concentrations did not differ between cows, when cows were dried off (Table 4). Plasma insulin concentration decreased $(P<0.001)$ and plasma glucagon concentration increased $(P<0.05)$ with onset of lactation. Plasma insulin concentration in 28-d DP cows increased during DP, whereas plasma insulin concentration in 90-d DP cows decreased at the same time (interaction DP $\times$ time: $P<0.01$; Figure $3 \mathrm{H}$, Table 4). After parturition, 28-d DP cows had higher insulin concentrations $(P<0.05)$ than 56-d DP cows and tended to have a higher insulin concentrations $(P<0.1)$ than $90-\mathrm{d}$ DP cows. The glucagon to insulin ratio increased $(P<0.01)$ after calving in all cows and decreased from 14 to 56 DIM without treatment effects.

\section{Liver Fat and Liver Glycogen Concentrations and Hepatic Gene Expression of Glucogenic Enzymes}

On d 10 before expected calving, LFC was considerably lower than on d 10 after calving $(P<0.01$; Table $5)$. Liver fat concentration after calving was higher $(P$ $<0.05)$ in 90-d than in 28-d DP cows. Liver glycogen concentration was not different among treatment groups before and after calving but decreased $(P<$ 0.01) after calving in all cows.

Abundance of $P C$ mRNA tended to increase highest after calving (interaction $P<0.1$ ) in 90-d DP cows (Table 5). Statistics for $P C K 1 \mathrm{mRNA}$ abundance revealed a trend $(P<0.1)$ for different changes during the transition period, namely an increase of $P C K 1$ mRNA in 28-d DP cows, but a decrease in 56- and 90-d DP cows (Table 5). Abundances of $G 6 P C$ mRNA were not affected by time and DP (Table 5 ).

\section{DISCUSSION}

Cows investigated in this study were kept under identical environmental conditions and were fed the same diets ad libitum. Dairy cows were randomly assigned to DP length of either 28 or $56 \mathrm{~d}$. Cows with 90-d DP length had low milk yield (15 kg/d or less) at the end of the previous lactation and were dried off, although they did not reach scheduled time point 


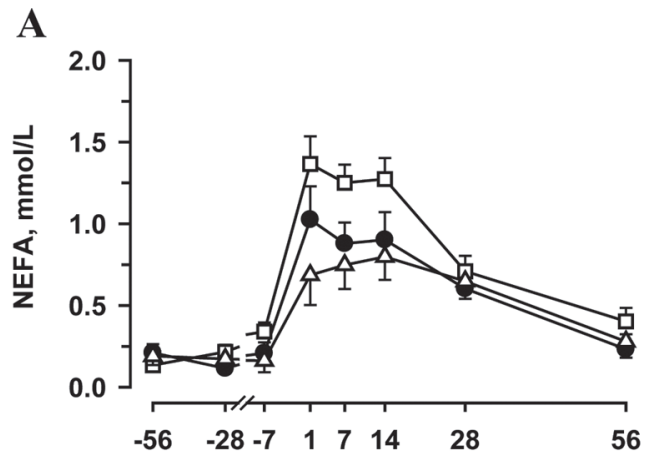

C

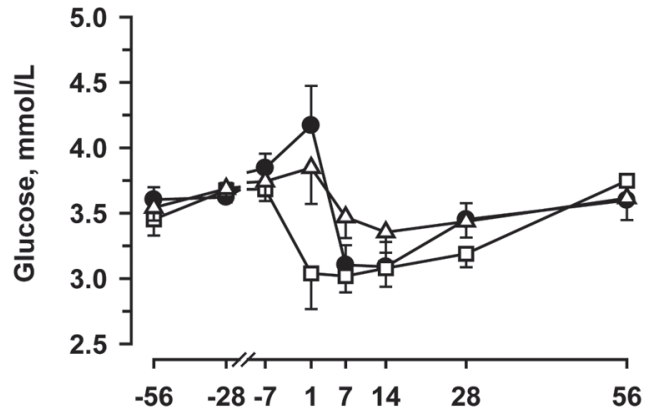

E

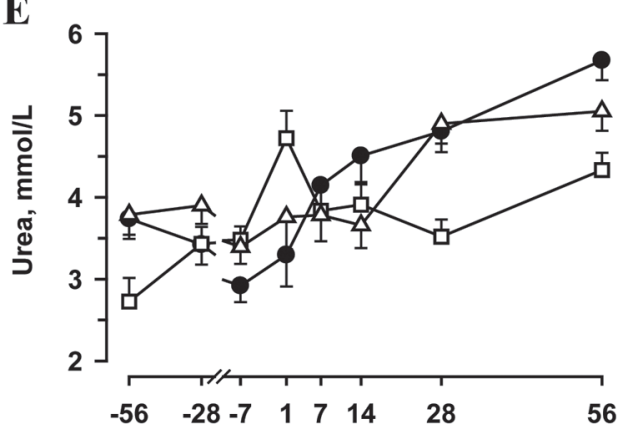

G

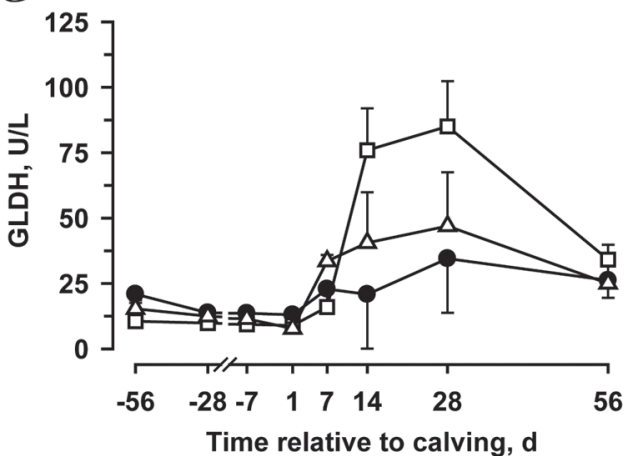

B

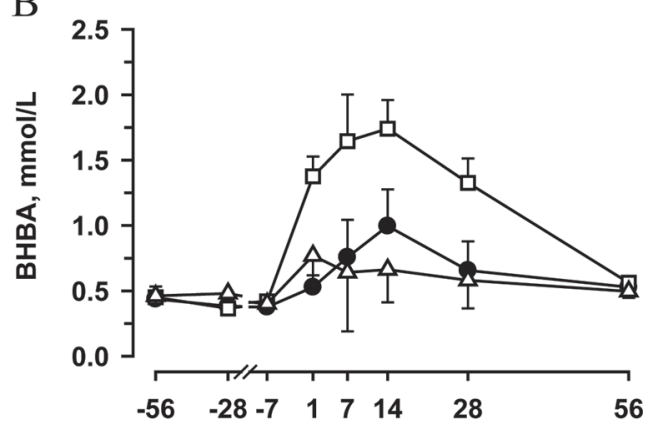

D

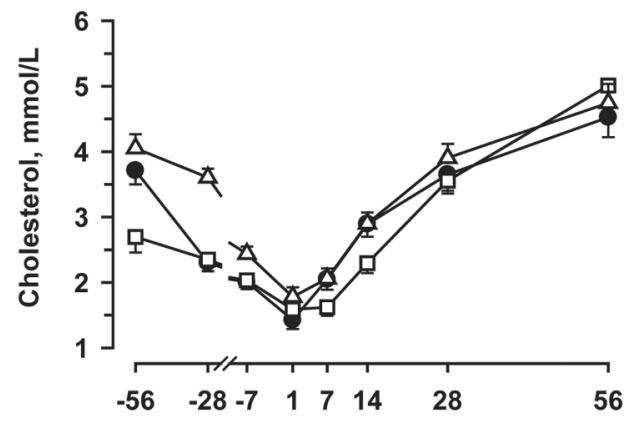

F

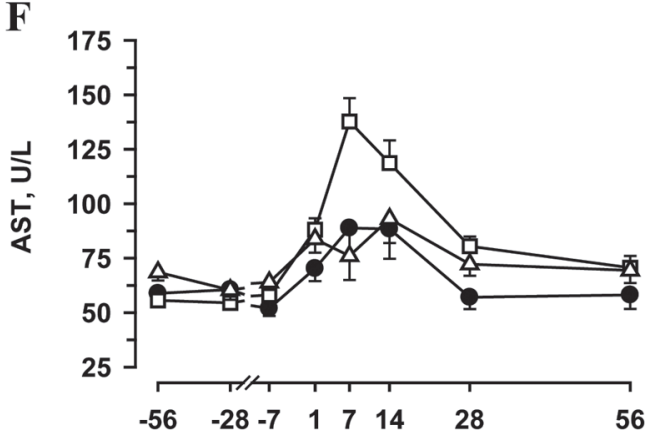

$\mathbf{H}$

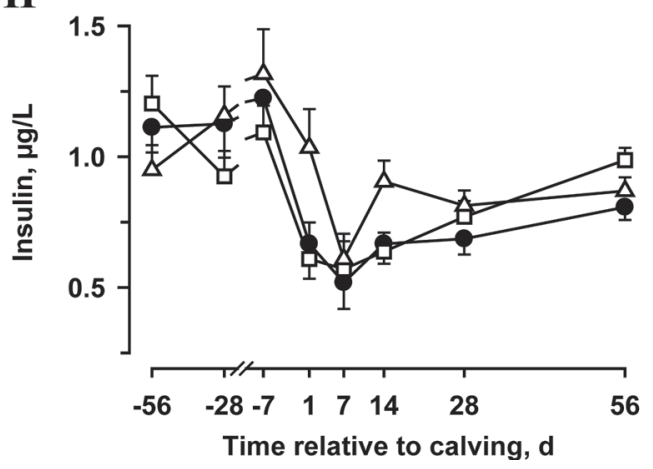

Figure 3. Plasma concentrations of NEFA (A), BHBA (B), glucose (C), cholesterol (D), urea (E), aspartate transaminase (AST; F), glutamate dehydrogenase (GLDH; G), and insulin $(\mathrm{H})$ from d 56 before expected calving to d 56 after calving in cows with $28-(\Delta)$, 56- $(\bullet)$, and $90-\mathrm{d}$ $(\square)$ dry period (DP) length. Data are presented as LSM \pm SE. Statistical analyses are provided in Table 4. 
Table 4. Plasma concentrations of NEFA, BHBA, glucose, cholesterol, urea, aspartate transaminase (AST), glutamate dehydrogenase (GLDH), insulin, and glucagon and the glucagon to insulin ratio in blood plasma on day of dry off (dry off), during the postpartum period (d 1 to 56 postpartum) and entire study ( $\mathrm{d}-56$ antepartum to d 56 postpartum) in cows with 28- $(\mathrm{n}=18), 56-(\mathrm{n}=18)$ and $90-\mathrm{d}(\mathrm{n}=22)$ dry period (DP) length

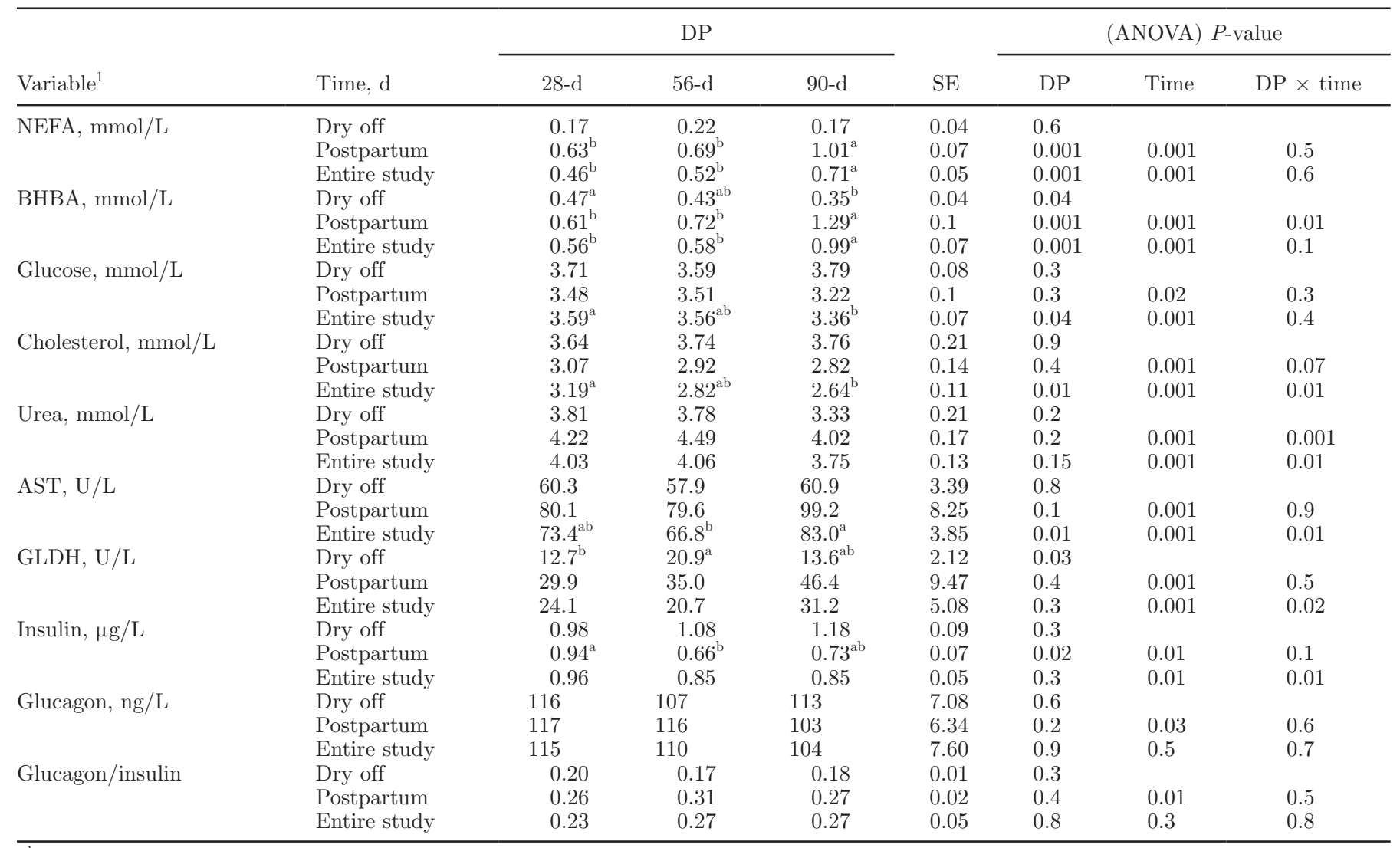

${ }^{\mathrm{a}, \mathrm{b}}$ Least squares means with different letters within a row are significantly different from each other (Tukey-Kramer test, $P<0.05$ ).

${ }^{1}$ Values are LSM with SE.

on end of lactation, namely 56-d before expected calving. Therefore, DP was inevitably longer than $56 \mathrm{~d}$. Cows with 90-d DP had a longer calving interval due to delayed conception. Reasons for this delay were variable, but reduced fertility in 90-d DP cows could be documented by elevated services per conception after

Table 5. Liver fat concentration (LFC), liver glycogen concentration (LGC), and hepatic mRNA abundance relative to reference gene of pyruvate carboxylase $(P C)$, cytosolic phosphoenolpyruvate carboxykinase $(P C K 1)$, and glucose-6-phosphatase $(G 6 P C)$ on d 10 before $(-10)$ expected calving and d 10 after calving $(10)$ in cows with 28- $(\mathrm{n}=11), 56-(\mathrm{n}=11)$, and $90-\mathrm{d}(\mathrm{n}=11)$ dry period $(\mathrm{DP})$ length

\begin{tabular}{|c|c|c|c|c|c|c|c|c|}
\hline Variable $^{1}$ & $\begin{array}{l}\text { Time, } \mathrm{d} \text { relative } \\
\text { to calving }\end{array}$ & \multicolumn{3}{|c|}{$\mathrm{DP}$} & $\mathrm{SE}$ & \multicolumn{3}{|c|}{$($ ANOVA) $P$-value } \\
\hline $\mathrm{LFC}, \mathrm{mg} / \mathrm{g}$ of $\mathrm{DM}$ & $\begin{array}{r}-10 \\
10\end{array}$ & $\begin{array}{l}152 \\
311^{\mathrm{b}}\end{array}$ & $\begin{array}{l}179 \\
384^{\text {ab }}\end{array}$ & $\begin{array}{l}220 \\
491^{\mathrm{a}}\end{array}$ & $\begin{array}{l}38.1 \\
40.1\end{array}$ & 0.02 & 0.001 & 0.3 \\
\hline $\mathrm{LGC}, \mathrm{mg} / \mathrm{g}$ of $\mathrm{DM}$ & $\begin{array}{r}10 \\
-10\end{array}$ & $\begin{array}{c}13.4 \\
3.53\end{array}$ & $\begin{array}{c}12.7 \\
1.27\end{array}$ & $\begin{array}{c}12.0 \\
0.34\end{array}$ & $\begin{array}{l}1.28 \\
2.06\end{array}$ & 0.2 & 0.001 & 0.7 \\
\hline Gene expression & & & & & & & & \\
\hline$P C K 1$ & $\begin{array}{r}-10 \\
10\end{array}$ & $\begin{array}{l}3.37 \\
4.09\end{array}$ & $\begin{array}{l}5.48 \\
1.83\end{array}$ & $\begin{array}{l}4.19 \\
2.53\end{array}$ & $\begin{array}{l}0.98 \\
1.03\end{array}$ & 0.9 & 0.07 & 0.1 \\
\hline$G 6 P C$ & $\begin{array}{r}-10 \\
10\end{array}$ & $\begin{array}{l}51.7 \\
63.2\end{array}$ & $\begin{array}{l}47.7 \\
35.6\end{array}$ & $\begin{array}{l}46.4 \\
42.5\end{array}$ & $\begin{array}{l}13.7 \\
14.1\end{array}$ & 0.6 & 0.9 & 0.6 \\
\hline
\end{tabular}

\footnotetext{
$\overline{\mathrm{a}, \mathrm{b}}$ Least squares means with different letters within a row are significantly different from each other (Tukey-Kramer test, $P<0.05$ ).

${ }^{1}$ Values are LSM with SE.
} 
previous calving (services per conception were 2.1, 1.9, and 3.4 for 28-, 56-, and 90-d DP cows, respectively). Cows did not differ in length of previous lactation period, although a numerical difference of about 50 DIM between 90- and 56-d DP cows was observed. Cows had same potential for milk production, as indicated by 305-d milk performance in previous lactation, but cows with conventional DP length $(56 \mathrm{~d})$ produced at dry off more milk than 90-d DP cows.

\section{Effects of Dry Period Length on Consecutive Milk Production and Body Condition}

We have found no differences in overall milk production during early lactation among DP lengths, as also indicated by others (Gulay et al., 2003; Santschi et al., 2011). This is in contrast to other studies that reported a reduced milk production in early lactation after a 30-d DP, compared with a 60-d DP (Rastani et al., 2005; van Knegsel et al., 2014). Time course of milk yield and ECM until 56 DIM behaved differently with respect to DP length, indicated by lowest milk yield at beginning of lactation, but highest milk yield at 56 DIM in 90-d DP cows. Milk yield in 56- and 28-d DP cows reached highest performance in wk 5 of lactation and started to decrease afterward. Milk production data in this study were further recorded, and cows with 90-d DP produced slightly more milk until 200 DIM, indicating greatest lactation persistence in 90-d DP cows, whereas 28-d DP cows showed lowest milk yield until 200 DIM. These data support previous findings that a shortened DP reduces milk persistence in the subsequent lactation (Pezeshki et al., 2008; de Feu et al., 2009; van Knegsel et al., 2013), and confirm elevated milk production in cows with a prolonged DP (Sørensen and Enevoldsen, 1991; Weglarzy, 2009).

Shortening the DP may impair subsequent milk production more in primiparous than multiparous cows (Annen et al., 2004; Santschi et al., 2011). In our study, young cows in second lactation benefit from prolonged DP and 90-d DP cows produced most milk in second lactation, which coincides to previous investigations on optimal DP length in young dairy cows (Kuhn et al., $2006)$. On the other hand, milk yield was clearly negatively affected in cows with 2nd lactation when DP was shortened, whereas in 56-d DP cows lactation number had no effect on milk production.

Protein and lactose yield per day increased with milk yield during the experimental period, but milk protein content was highest in 28-d DP cows. At the same time, milk fat content was not affected by DP length, resulting in an elevated milk fat to protein ratio in 90-d DP cows. Increased milk protein content with respect to reduced DP length is well known from literature (Rastani et al., 2005; Watters et al., 2008; van Knegsel et al., 2014) and is probably the consequence of reduced milk volume but same potential for milk protein synthesis in 28-d DP cows. Whether an improved energy balance in 28-d DP cows may have contributed to elevated milk protein content in our study, as suggested by Watters et al. (2008), is not known because we could not calculate energy balance. With regard to milk protein content, elevated insulin status after calving in 28-d DP cows may affect milk protein synthesis probably by stimulating mammary blood flow and glucose uptake into the mammary gland (Bequette et al., 2001). Milk lactose content increased and milk fat content decreased at the same time during early lactation, which is in accordance to previous studies (Hammon et al., 2009; Weber et al., 2013b). However, the enhanced fat mobilization in 90-d DP cows did not result in a greater milk fat content, which was the case in an earlier study (Hammon et al., 2009). One reason for the absence of elevated milk fat in 90-d DP cows might be the less frequent milk sampling in our study. Concerning milk urea concentration in 90-d DP cows, the low concentration may point to a slightly insufficient protein supply in cows with a prolonged DP, although concentration was in a physiological range (Schepers and Meijer, 1998). Fat mobilization and the fat to protein ratio in milk were elevated in 90-d DP cows. Therefore, we speculate that DMI was probably lower in 90-d DP cows than in 56and 28-d DP cows and that the reduction in DMI led to a slightly insufficient protein supply in 90-d DP cows. Our previous findings in dairy cows clearly demonstrated a negative relationship between fat mobilization and DMI during the transition from pregnancy to lactation (Hammon et al., 2009; Weber et al., 2013b).

Our study did not confirm an improved body condition in dairy cows after calving, when DP length was reduced from about $8 \mathrm{wk}$ (conventional DP) to about 4 wk (shortened DP), as indicated in several studies (Rastani et al., 2005; Watters et al., 2008; Pezeshki et al., 2008; van Knegsel et al., 2014). Otherwise, BW and BCS were not affected by shortened DP length in the study of Santschi et al. (2011). The absence of DP effects on body condition after calving could be expected because milk yield did not differ between cows with 28- or 56-d DP.

On the other hand, BW and body condition before calving differed between 90-d DP cows and cows with 28- and 56-d DP length. Cows with 90-d DP were not chosen randomly, but had low milk production $(\leq 15$ $\mathrm{kg} / \mathrm{d}$ ) around $90 \mathrm{~d}$ before calving and, therefore, could not be assigned to 1 of the other 2 treatments. Interestingly, 90-d DP cows had greater BW, BFT, and BCS than cows of the other 2 treatments at dry off, indicating that nutrient partitioning in these cows focused 
more on fat accretion and less on milk production when compared with 28- and 56-d DP cows. This is also supported by the fact that milk yield at dry off was lowest in 90-d DP cows, although the lactation period was not different among treatment groups. At the end of the study at 56 DIM, BW and BFT were comparable among treatments. The decline of subcutaneous back fat in cows with prolonged DP (90 d) until 56 DIM was accompanied by rising milk yield in 90-d DP cows. This indicates that 90-d DP cows used much more body fat as energy fuel for milk production than cows of the other 2 treatments. Interestingly, BW loss after calving stopped much earlier (wk 2 after calving) in all cows than loss of BFT or reduction in BCS after calving (wk 4 or 8 after calving), indicating that body mass such as muscle tissue or fat depots others than subcutaneous fat were rebuilt at the same time when subcutaneous fat was still degraded, which supports previous findings in transition cows (Hammon et al., 2009; Weber et al., 2013b).

\section{Associations Between Dry Period Length and Metabolic Parameters in Blood Plasma and Liver}

Cows with prolonged (90 d) DP and elevated BFT before calving had greatest plasma NEFA and BHBA release during the transition period. On the other hand, plasma NEFA release in 28- and 56-d DP cows did not differ between each other, was less conspicuous, and was not reflected by an appropriate postnatal BHBA release in blood plasma. The effect of shortened DP length on NEFA release around calving mostly results in a reduced NEFA release during the transition period, as reviewed by van Knegsel et al. (2013), but Rastani et al. (2005) found no effect on plasma NEFA release when comparing 56- and 28-d DP cows.

The association between elevated body condition before calving and enhanced lipolysis around calving that result in increased hepatic ketone body formation and elevated liver fat content is well known in dairy cows (Grummer, 1993; Hammon et al., 2009; Weber et al., 2013b). Elevated lipolysis and hepatic NEFA uptake exceeded the capacity for fatty acid oxidation primarily in liver of 90-d DP cows, whereas the increase of plasma NEFA and of hepatic liver fat was less pronounced in 28-d DP cows. As a consequence, postnatal increase of plasma BHBA was much lower due to either less hepatic NEFA uptake or improved complete utilization of fatty acids by the liver (Ingvartsen and Andersen, 2000; Drackley et al., 2001; Bobe et al., 2004). This was the case in cows with conventional and shortened DP length. Greater plasma BHBA concentration after calving was related to elevated plasma concentrations of AST and GLDH in dairy cows (Hachenberg et al., 2007; Kessel et al., 2008). Although clinically not relevant, elevated plasma concentrations of AST and GLDH might indicate a trend for an impaired liver cell function in 90-d DP cows. These increases were highly reversible because elevated plasma levels of AST and GLDH ceased at 56 DIM.

After calving, glucose is primarily used in the mammary gland and, therefore, plasma glucose concentration decreased after calving in all treatment groups. Plasma glucose concentration was lowest immediately after calving in 90-d DP cows and exhibited the lowest transition changes from pregnancy to lactation in cows with 28-d DP. The decrease of plasma glucose concentration after calving is more pronounced in cows with elevated fat mobilization and fat concentration in liver (Ohgi et al., 2005; Hammon et al., 2009; Weber et al., 2013b), which was also observed in our study. In addition, the minor transition changes in plasma glucose of 28-d DP cows fitted to the elevated postpartum insulin concentration, compared with cows with 56-d DP length. A recent published review indicated that a shortened DP length improves the plasma glucose and insulin status in dairy cows (van Knegsel et al., 2013). Consistent with the changes in plasma glucose and insulin concentrations around calving, LGC rapidly decreased with onset of lactation to provide glucose for milk production and to counterbalance the low plasma glucose concentration after calving (Herdt, 2000; Hammon et al., 2009; Weber et al., 2013b). In contrast to changes in plasma glucose and insulin, the decrease of LGC did not differ with respect to DP length.

Pyruvate carboxylase, phosphoenolpyruvate carboxykinase, and glucose-6-phosphatase are crucial in ruminant hepatic gluconeogenesis to ensure a high glucose production during early lactation (Aschenbach et al., 2010; Weber et al., 2013a). Gene expression of these enzymes increased during the transition from pregnancy to lactation, but mRNA abundance of gluconeogenic enzymes peaked at different time points (Greenfield et al., 2000; Hammon et al., 2009; Weber et al., 2013a). Gene expression of $P C$ increased immediately at calving, whereas gene expression of $P C K 1$ and $G 6 P C$ increased gradually together with postcalving increment of DMI (Greenfield et al., 2000; Hammon et al., 2009; Weber et al., 2013b). Reduced DMI at calving has a great impact on hepatic $P C$ gene expression and gene expression of $P C$, but gene expression of $P C K 1$ did not increase during feed restriction in dairy cows (Velez and Donkin, 2005; Loor et al., 2006).

The mRNA abundance of hepatic $P C$ after calving increased in our study to the greatest extent in 90-d DP cows. This is consistent with previous findings that in 
cows with elevated fat mobilization and hepatic liver fat content, the increase of $P C$ mRNA in liver immediately after birth is most obvious (Weber et al., 2013a). This was probably related to the reduced DMI at calving, as assumed especially for 90-d DP cows. Hepatic PCK1 mRNA tended to decrease from $10 \mathrm{~d}$ before expected calving to $10 \mathrm{~d}$ after calving in 56- and 90-d DP cows, whereas $G 6 P C$ did not show changes around calving. Changes in PCK1 mRNA were consistent with previous findings (Weber et al., 2013a) and the decrease of hepatic PCK1 mRNA after calving probably mirrored the insufficient propionate availability in 56- and 90-d DP cows (Aschenbach et al., 2010; Weber et al., 2013a). The short time period from calving to 10 DIM did not cause an increase of hepatic PCK1 mRNA abundance, as seen in previous studies (Greenfield et al., 2000; Weber et al., 2013a).

Elevated plasma NEFA and BHBA concentrations, reduced plasma glucose concentration as well as an elevated fat to protein ratio in milk and greater hepatic fat storage after calving pointed to a more severe negative energy balance in 90-d DP cows (Reist et al., 2003; Hammon et al., 2009; Weber et al., 2013b). On the other hand, elevated postpartum plasma insulin concentration may indicate an improved energy status in 28-d DP cows (Reist et al., 2003; Weber et al., 2013b). It is well known that DP length affects energy balance during the transition period and that a shortened DP improves energy balance after calving, mainly because of reduced milk performance (Rastani et al., 2005). Furthermore, in continuously milked cows with omitted DP, plasma metabolites were consistent with an improved energy balance (Grummer and Rastani, 2004; van Knegsel et al., 2013). The improved energy balance is considered as one of the main causes for the reduced incidence of metabolic related disorders, such as fatty liver or ketosis (Goff and Horst, 1997).

Greatest changes in plasma urea concentration were seen in 90-d DP cows with a peak immediately after calving. This peak of plasma urea was probably the consequence of elevated amino acid degradation. During the transition from pregnancy to lactation, when feed intake increase is insufficient and propionate provision does not meet glucose requirements for lactation, other substances such as lactate and amino acids cover substrate demands for endogenous glucose production (Aschenbach et al., 2010). The increase in hepatic PC mRNA abundance of 90-d DP cows supports our hypothesis that cows with prolonged DP had greater need for amino acid utilization to provide alternative substrates for gluconeogenesis (Brockman, 2005). On the contrary, reduced plasma urea concentration at 28 and 56 DIM may mirror a relative deficit in nitrogen supply in 90-d DP cows that was discussed above with respect to reduced milk urea content in 90-d DP cows.

Plasma cholesterol indicated lowest concentration at calving in all cows, as seen in previous studies (Bernabucci et al., 2004; Duske et al., 2009; Weber et al., 2013b). Differences in plasma cholesterol before calving were obviously the consequence of different diets before calving (far-off, close-up, and lactation diet). Although diets were not investigated for cholesterol and there was probably no difference in cholesterol content, cholesterol synthesis might be affected by diet, as seen in previous studies (Douglas et al., 2007; Duske et al., 2009).

In conclusion, extended DP length (90 d) was associated with increased body fatness before calving and enhanced fat mobilization and pronounced systemic and hepatic metabolic aberrations during the transition from pregnancy to lactation. It is hard to speculate whether greater body condition in 90-d DP cows was a consequence of low milk yield at the end of lactation or the other way around. Probably, 90-d DP cows differ in regulation of nutrient partitioning between the mammary gland and other tissues such as fat and muscle tissue when compared with 28- or 56-d DP cows. Whether differences in nutrient partitioning are a consequence of reduced function of the mammary gland or have other causes cannot be answered by this study and warrant further investigations. On the contrary, changes in glucose and lipid metabolism were moderate when the DP was shortened or of traditional length. However, milk yield in early lactation was not affected by DP length, but lactation persistency (level of milk production after peak lactation) seems to be improved in cows with extended DP. The study emphasize on the importance of precalving body condition and DP length on milk performance and metabolic adaptation for consecutive lactation in dairy cows. A cow-individual DP management is probably needed for cows with extended DP length (e.g., by adaptation of diet) to avoid overconditioned cows that run into metabolic imbalances during the transition from pregnancy to lactation.

\section{ACKNOWLEDGMENTS}

The authors gratefully acknowledge the laboratory staff (Claudia Reiko, Brigitte Waischnow, Anne-Kathrin Lohrenz) of the Institute of Nutritional Physiology, FBN Dummerstorf, and of the State Institute of Animal Production Mecklenburg-Vorpommern, Dummerstorf (Jana Flor, Burkhard Hallier), as well as the support of the GUT Dummerstorf GmbH, Dummerstorf. Weidong Yang received a travel grant from the German-Chinese governmental exchange program. 


\section{REFERENCES}

Annen, E. L., R. J. Collier, M. A. McGuire, J. L. Vicini, J. M. Ballam, and M. J. Lormore. 2004. Effect of modified dry period lengths and bovine somatotropin on yield and composition of milk from dairy cows. J. Dairy Sci. 87:3746-3761.

Aschenbach, J. R., N. B. Kristensen, S. S. Donkin, H. M. Hammon, and G. B. Penner. 2010. Gluconeogenesis in dairy cows: The secret of making sweet milk from sour dough. IUBMB Life 62:869-877.

Bachman, K. C., and M. L. Schairer. 2003. Invited review: Bovine studies on optimal lengths of dry periods. J. Dairy Sci. 86:30273037.

Bequette, B. J., C. E. Kyle, L. A. Crompton, V. Buchan, and M. D. Hanigan. 2001. Insulin regulates milk production and mammary gland and hind-leg amino acid fluxes and blood flow in lactating goats . J. Dairy Sci. 84:241-255.

Bernabucci, U., B. Ronchi, L. Basiricò, D. Pirazzi, F. Rueca, N Lacetera, and A. Nardone. 2004. Abundance of mRNA of apolipoprotein B100, apolipoprotein E, and microsomal triglyceride transfer protein in liver from periparturient dairy cows. J. Dairy Sci. 87:2881-2888.

Bobe, G., J. W. Young, and D. C. Beitz. 2004. Invited review: Pathology, etiology, prevention, and treatment of fatty liver in dairy cows. J. Dairy Sci. 87:3105-3124.

Brockman, R. P. 2005. Glucose and short-chain fatty acid metabolism. Pages 291-310 in Quantitative Aspects of Ruminant Digestion and Metabolism. J. Dijkstra, J. M. Forbes, and J. France, ed. CAB International, Oxfordshire, UK.

de Feu, M. A., A. C. Evans, P. Lonergan, and S. T. Butler. 2009. The effect of dry period duration and dietary energy density on milk production, bioenergetic status, and postpartum ovarian function in Holstein-Friesian dairy cows. J. Dairy Sci. 92:6011-6022.

Douglas, G. N., J. Rehage, A. D. Beaulieu, A. O. Bahaa, and J. K. Drackley. 2007. Prepartum nutrition alters fatty acid composition in plasma, adipose tissue, and liver lipids of peripaturient dairy cows. J. Dairy Sci. 90:2941-2959.

Drackley, J. K., T. R. Overton, and G. N. Douglas. 2001. Adaptations of glucose and long-chain fatty acid metabolism in liver of dairy cows during the periparturient period. J. Dairy Sci. 84 (E Suppl.):E100-E112.

Duske, K., H. M. Hammon, A. K. Langhof, O. Bellmann, B. Losand, K. Nurnberg, G. Nurnberg, H. Sauerwein, H. M. Seyfert, and C. C. Metges. 2009. Metabolism and lactation performance in dairy cows fed a diet containing rumen-protected fat during the last twelve weeks of gestation. J. Dairy Sci. 92:1670-1684.

Edmonson, A. J., I. J. Lean, L. D. Weaver, T. Farver, and G. Webster. 1989. A Body condition scoring chart for Holstein dairy cows. J. Dairy Sci. 72:68-78.

German Society of Nutrition Physiology. 2008. Ausschuss für Bedarfsnormen der Gesellschaft für Ernährungsphysiologie, No. 9. Empfehlungen zur Energie- und Nährstoffversorgung der Milchkühe und Aufzuchtrinder (Recommended energy and nutrient supply for dairy cows and growing cattle). in DLG Verlag Frankfurt a. Main, Germany.

Goff, J. P., and R. L. Horst. 1997. Physiological changes at parturition and their relationship to metabolic disorders. J. Dairy Sci. 80:1260-1268.

Greenfield, R. B., M. J. Cecava, and S. S. Donkin. 2000. Changes in mRNA expression for gluconeogenic enzymes in liver of dairy cattle during the transition to lactation. J. Dairy Sci. 83:1228-1236.

Grummer, R. R. 1993. Etiology of lipid-related metabolic disorders in periparturient dairy cows. J. Dairy Sci. 76:3882-3896.

Grummer, R. R., and R. R. Rastani. 2004. Why reevaluate dry period length? J. Dairy Sci. 87(E. Suppl.):E77-E85.

Gulay, M. S., M. J. Hayen, K. C. Bachman, T. Belloso, M. Liboni, and H. H. Head. 2003. Milk production and feed intake of Holstein cows given short (30-d) or normal (60-d) dry periods. J. Dairy Sci. 86:2030-2038.

Hachenberg, S., C. Weinkauf, S. Hiss, and H. Sauerwein. 2007. Evaluation of classification modes potentially suitable to identify meta- bolic stress in healthy dairy cows during the peripartal period. J. Anim. Sci. 85:1923-1932.

Hammon, H. M., G. Stürmer, F. Schneider, A. Tuchscherer, H. Blum, T. Engelhard, A. Genzel, R. Staufenbiel, and W. Kanitz. 2009. Performance and metabolic and endocrine changes with emphasis on glucose metabolism in high-yielding dairy cows with high and low fat content in liver after calving. J. Dairy Sci. 92:1554-1566.

Herdt, T. H. 2000. Ruminant adaptation to negative energy balance. Influence of the etiology of ketosis and fatty liver. Vet. Clin. North Am. Food Anim. Pract. 16:215-230.

Ingvartsen, K. L., and J. B. Andersen. 2000. Integration of metabolism and intake regulation: A review focusing on periparturient animals. J. Dairy Sci. 83:1573-1597.

Kessel, S., M. Stroehl, H. H. D. Meyer, S. Hiss, H. Sauerwein, F. J. Schwarz, and R. M. Bruckmaier. 2008. Individual variability in physiological adaptation to metabolic stress during early lactation in dairy cows kept under equal conditions. J. Anim. Sci. 86:2903-2912.

Kuhn, M. T., J. L. Hutchison, and H. D. Norman. 2006. Dry period length to maximize production across adjacent lactations and lifetime production. J. Dairy Sci. 89:1713-1722.

Linzell, J. L. 1972. Mechanism of secretion of the aqueous phase of milk. J. Dairy Sci. 55:1316-1322.

Loor, J. J., H. M. Dann, N. A. J. Guretzky, R. E. Everts, R. Oliveira, C. A. Green, N. B. Litherland, S. L. Rodriguez-Zas, H. A. Lewin, and J. K. Drackley. 2006. Plane of nutrition prepartum alters hepatic gene expression and function in dairy cows as assessed by longitudinal transcript and metabolic profiling. Physiol. Genomics 27:29-41.

Naumann, C., and R. Bassler. 2004. Die chemische Untersuchung von Futtermittel. VDLUFA-Verlag, Darmstadt, Germany.

Ohgi, T., S. Kamimura, Y. Minezaki, and M. Takahashi. 2005. Relationship between fat accumulation in the liver and energy intake, milk fat yield and blood metabolites in dairy cows. Anim. Sci. J. 76:549-557.

Pezeshki, A., J. Mehrzad, G. R. Ghorbani, B. De Spiegeleer, R. J. Collier, and C. Burvenich. 2008. The effect of dry period length reduction to 28 days on the performance of multiparous dairy cows in the subsequent lactation. Can. J. Anim. Sci. 88:449-456.

Pfaffl, M. W. 2001. A new mathematical model for relative quantification in real-time RT-PCR. Nucleic Acids Res. 29:e45.

Rastani, R. R., R. R. Grummer, S. J. Bertics, A. Gumen, M. C. Wiltbank, D. G. Mashek, and M. C. Schwab. 2005. Reducing dry period length to simplify feeding transition cows: Milk production, energy balance, and metabolic profiles. J. Dairy Sci. 88:1004-1014.

Reist, M., D. Erdin, D. von Euw, K. Tschuemperlin, H. Leuenberger, C. Delavaud, Y. Chilliard, H. M. Hammon, N. Kuenzi, and J. W. Blum. 2003. Concentrate feeding strategy in lactating dairy cows: Metabolic and endocrine changes with emphasis on leptin. J. Dairy Sci. 86:1690-1706.

Rigout, S., S. Lemosquet, J. E. van Eys, J. W. Blum, and H. Rulquin. 2002. Duodenal glucose increases glucose fluxes and lactose synthesis in grass silage-fed dairy cows. J. Dairy Sci. 85:595-606.

Santschi, D. E., D. M. Lefebvre, R. I. Cue, C. L. Girard, and D. Pellerin. 2011. Complete-lactation milk and component yields following a short (35-d) or a conventional (60-d) dry period management strategy in commercial Holstein herds. J. Dairy Sci. 94:2302-2311.

Schepers, A. J., and R. G. M. Meijer. 1998. Evaluation of the utilization of dietary nitrogen by dairy cows based on urea concentration in milk. J. Dairy Sci. 81:579-584.

Schröder, U. J., and R. Staufenbiel. 2006. Invited review: Methods to determine body fat reserves in the dairy cow with special regard to ultrasonographic measurement of back fat thickness. J. Dairy Sci. 89:1-14.

Sørensen, J. T., and C. Enevoldsen. 1991. Effect of dry period length on milk production in subsequent lactation. J. Dairy Sci. 74:1277-1283.

van Knegsel, A. T., G. J. Remmelink, S. Jorjong, V. Fievez, and B. Kemp. 2014. Effect of dry period length and dietary energy source 
on energy balance, milk yield, and milk composition of dairy cows. J. Dairy Sci. 97:1499-1512.

van Knegsel, A. T., S. G. A. van der Drift, J. Čermáková, and B. Kemp. 2013. Effects of shortening the dry period of dairy cows on milk production, energy balance, health, and fertility: A systematic review. Vet. J. 198:707-713.

Velez, J. C., and S. S. Donkin. 2005. Feed restriction induces pyruvate carboxylase but not phosphoenolpyruvate carboxykinase in dairy cows. J. Dairy Sci. 88:2938-2948.

Vicari, T., J. J. G. C. van den Borne, W. J. J. Gerrits, Y. Zbinden, and J. W. Blum. 2008. Postprandial blood hormone and metabolite concentrations influenced by feeding frequency and feeding level in veal calves. Domest. Anim. Endocrinol. 34:74-88.

Watters, R. D., J. N. Guenther, A. E. Brickner, R. R. Rastani, P. M. Crump, P. W. Clark, and R. R. Grummer. 2008. Effects of dry period length on milk production and health of dairy cattle. J. Dairy Sci. 91:2595-2603.
Weber, C., C. Hametner, A. Tuchscherer, B. Losand, E. Kanitz, W. Otten, H. Sauerwein, R. M. Bruckmaier, F. Becker, W. Kanitz, and H. M. Hammon. 2013a. Hepatic gene expression involved in glucose and lipid metabolism in transition cows: Effects of fat mobilization during early lactation in relation to milk performance and metabolic changes. J. Dairy Sci. 96:5670-5681.

Weber, C., C. Hametner, A. Tuchscherer, B. Losand, E. Kanitz, W. Otten, S. P. Singh, R. M. Bruckmaier, F. Becker, W. Kanitz, and H. M. Hammon. 2013b. Variation in fat mobilization during early lactation differently affects feed intake, body condition, and lipid and glucose metabolism in high-yielding dairy cows. J. Dairy Sci 96:165-180.

Weglarzy, K. 2009. Lactation productivity of dairy cows as affected by the length of preceding dry period. Anim. Sci. Pap. Rep. $27: 303-310$ 